\title{
Index to Volume 71
}

Abele, F. (See Southcott, C.)

Adams, P., and Brunger, A. (Book Review) Four Antarctic Years in the Southern Orkney Islands: An Annotated Translation of Cuatro Años en las Orcadas del Sur, by José Manuel Moneta. Translated by Kathleen Skilton and Kenn Back; edited by Robert K. Headland. 71(3):350-351.

Alfonso, N. (See Crawford, R.E.)

Amarualik, N. (See Crawford, R.E.)

Amarualik, P., Sr. (See Crawford, R.E.)

Antoine, A. (See Straka, J.R.)

AOS Executive Committee Members. (InfoNorth) Arctic Observing Summit (AOS) 2018 Statement and Call to Action. 71(3):360-361.

Atkinson, D. (See Paquette-Struger, B.)

Barr, W. (Book Review) Dead Reckoning: The Untold Story of the Northwest Passage, by Ken McGoogan. 71(1):100-101. . (Book Review) Island of the Blue Foxes: Disaster and Triumph on the World's Greatest Scientific Expedition, by Stephen R. Bown. 71(2):230-232.

—. (InfoNorth) Boris Aleksandrovich Kremer (1908-76) Polyarnik. 71(2):237-245.

—. (Obituary) William Peter Adams (1936-2018). 71(4): $463-464$.

Bentzen, R., Liebezeit, J., Robards, M., Streever, B., Strindberg, S., and Zack, S. Bird Use of Northern Alaska Oilfield Rehabilitation Sites. 71(4):422-430.

Betcher, S. (See Dammann, D.O.)

Blais, J.M. (See Stewart, E.M.)

Blum, H. (Book Review) The Greatest Show in the Arctic: The American Exploration of Franz Josef Land, 1895-1905, by P.J. Capelotti. 71(3):351-352.

Boadway, K.A. (See Pratte, I.)

Brattland, C., and Mustonen, T. How Traditional Knowledge Comes to Matter in Atlantic Salmon Governance in Norway and Finland. 71(4):375-392.

Brower, A.A. (See Clarke, J.T.)

Brunger, A. (See Adams, P.)

Bruning, D.L. (See Glassburn, C.L.)

Bruno, R. (See Straka, J.R.)

Buddle, C.M. (See Ste-Marie, E.)

Burn, C.R. (Obituary) Diana Mary Rustat Rowley, née Crowfoot (1918-2018). 71(4):465-466.

Butler, M.G. (See McEwen, D.C.)

Cairns, D.M. (See Dwight, R.A.)

Cameron, M.D. (See Joly, K.)

Campbell, D. (See Straka, J.R.)

Campbell, Ron (See Straka, J.R.)

Campbell, Ross (See Straka, J.R.)

Cardinal, J. (See Straka, J.R.)

Cavell, J. Who Discovered the Northwest Passage? 71(3):292 - 308.

Checkley, S.L. (See Tomaselli, M.)

Chen, A. (InfoNorth) Ecological Recovery after Fire in the Tundra Plains Ecoregion. 71(4):473-476.
Christie, L. (InfoNorth) Understanding How Sea Ice Influences Arctic Deep-Water Food Webs across a Latitudinal Gradient. 71(4):467-472.

Clark, J.L. (See Glassburn, C.L.)

Clarke, J.T., Ferguson, M.C., Willoughby, A.L., and Brower, A.A. Bowhead and Beluga Whale Distributions, Sighting Rates, and Habitat Associations in the Western Beaufort Sea in Summer and Fall 2009-16, with Comparison to 1982-91. 71(2):115-138.

Community of Iqaluktutiaq (See Tomaselli, M.)

Copland, L. (See Dawson, J.)

Countryman, A.M. (See Nong, D.)

Crawford, R.E., Striano, E., Amarualik, P., Sr., Amarualik, N., Cumbaa, S.L., Alfonso, N., and Fisk, A.T. (InfoNorth) Four Hundred and Fifty-Year-Old Skeletal Remains of Atlantic Cod (Gadus morhua) Found on Multiyear Ice in High Arctic Canada. 71(1):109-112.

Cumbaa, S.L. (See Crawford, R.E.)

Dammann, D.O., Eicken, H., Mahoney, A.R., Meyer, F.J., and Betcher, S. Assessing Sea Ice Trafficability in a Changing Arctic. 71(1):59-75.

Dawson, J., Pizzolato, L., Howell, S.E.L., Copland, L., and Johnston, M.E. Temporal and Spatial Patterns of Ship Traffic in the Canadian Arctic from 1990 to 2015. 71(1):15-26.

Di Cenzo, P. (See Paquette-Struger, B.)

Diamond, A.W. (See Pratte, I.)

Dwight, R.A., and Cairns, D.M. The Trans-Alaska Pipeline System Facilitates Shrub Establishment in Northern Alaska. 71(3):249-258.

Eicken, H. (See Dammann, D.O.)

Elverum, S.L.K. (Book Review) Arcticness: Power and Voice from the North, edited by Ilan Kelman. 71(4):456-457.

Fanning, L.M. (See Keenan, E.)

Ferguson, M.C. (See Clarke, J.T.)

Fisk, A.T. (See Crawford, R.E.)

Freire, F. (See Lomac-MacNair, K.)

Frisch, T. (Obituary) Robert Gordon Blackadar (1928-2017). 71(1):107-108.

Gerlach, S.C. (See Tomaselli, M.)

Gibot, G. (See Straka, J.R.)

Gilotti, J.A. (Book Review) A Symphony of Scenic Beauty Avannaarsua: Greenland's Farthest North, by Peter R. Dawes and Jakob Lautrup. 71(4):457-458.

Glassburn, C.L., Potter, B.A., Clark, J.L., Reuther, J.D., Bruning, D.L., and Wooller, M.J. Strontium and Oxygen Isotope Profiles of Sequentially Sampled Modern Bison (Bison bison bison) Teeth from Interior Alaska as Proxies of Seasonal Mobility. 71(2):183-200.

Gray, Q.Z. (See Straka, J.R.)

Grey, E.K. (See Nong, D.) 
Hansen, A.M., and Virginia, R.A. The Future of Hydrocarbon Development in Greenland: Perspectives from Residents of the North Slope of Alaska. 71(4):365-374.

Hargan, K.E. (See Stewart, E.M.)

Hébert, J.S. (See Laforest, B.J.)

Hogan, K. (See Lomac-MacNair, K.)

Howell, S.E.L. (See Dawson, J.)

Irwin, S. (See Straka, J.R.)

Jakobsson, M. (See Lomac-MacNair, K.)

Johnston, M.E. (See Dawson, J.)

Joly, K., Sorum, M.S., and Cameron, M.D. Denning Ecology of Wolves in East-Central Alaska, 1993 -2017. 71(4):444-455.

Kaplan, S.A. (Book Review) The Polar Adventures of a Rich American Dame: A Life of Louise Arner Boyd, by Joanna Kafarowski. 71(4):460-461.

Keenan, E., Fanning, L.M., and Milley, C. Mobilizing Inuit Qaujimajatuqangit in Narwhal Management through Community Empowerment: A Case Study in Naujaat, Nunavut. 71(1):27-39.

Kietäväinen, A. (See Turunen, M.T.)

Kimpe, L.E. (See Stewart, E.M.)

Kindopp, R. (See Straka, J.R.)

Kouzov, S., Zaynagutdinova, E., Sagitov, R., and Rychkova, A. Nesting of Barnacle Goose (Branta leucopsis) in the Russian Part of the Gulf of Finland. 71(1):76-88.

Kutz, S.J. (See Tomaselli, M.)

Ladouceur, R. (See Straka, J.R.)

Ladouceur, W. (See Straka, J.R.)

Laforest, B.J., Hébert, J.S., Obbard, M.E., and Thiemann, G.W. Traditional Ecological Knowledge of Polar Bears in the Northern Eeyou Marine Region, Québec, Canada. 71(1):40 - 58.

Lankshear, J. (See Straka, J.R.)

Liebezeit, J. (See Bentzen, R.)

Ljubicic, G.J., Okapkok, S., Robertson, S., and Mearns, R. Inuit Approaches to Naming and Distinguishing Caribou: Considering Language, Place, and Homeland toward Improved Co-management. 71(3):309-333.

Lomac-MacNair, K., Jakobsson, M., Mix, A., Freire, F., Hogan, K., Mayer, L., and Smultea, M.A. Seal Occurrence and Habitat Use during Summer in Petermann Fjord, Northwestern Greenland. 71(3):334-348.

Maclean, B. (See Straka, J.R.)

Macmillan, S. (See Straka, J.R.)

Mahoney, A.R. (See Dammann, D.O.)

Mallory, M.L. (See Pratte, I.)

Marcel F. (See Straka, J.R.)

Marten, G. (See Straka, J.R.)

Marten, L. (See Straka, J.R.)

Mason, C.W. (See Thompson, H.A.)

Mayer, L. (See Lomac-MacNair, K.)

McCullough, K. (Commentary) How Time Flies! 71(2):iii.
McEwen, D.C., and Butler, M.G. Growing-Season Temperature Change across Four Decades in an Arctic Tundra Pond. 71(3):281-291.

McKinnon, J. (See Straka, J.R.)

Mearns, R. (See Ljubicic, G.)

Meyer, F.J. (See Dammann, D.O.)

Milley, C. (See Keenan, E.)

Millman, L. (Book Review) George Cartwright's The Labrador Companion, edited by Marianne P. Stopp. 71(1):99-100.

Mix, A. (See Lomac-MacNair, K.)

Mustonen, T. (See Brattland, C.)

Natcher, D. (See Southcott, C.)

Nong, D., Countryman, A.M., Warziniack, T., and Grey, E.K. Arctic Sea Routes: Potential New Pathways for Nonindigenous Species Spread. 71(3):269-280.

Norton, D.W. (Book Review) The Great Quake: How the Biggest Earthquake in North America Changed Our Understanding of the Planet, by Henry Fountain. 71(1):101-103.

___. (Book Review) Melting the Ice Curtain: The Extraordinary Story of Citizen Diplomacy on the RussiaAlaska Frontier, by David Ramseur. 71(1):104-105.

___ (Book Review) The Arctic Guide: Wildlife of the Far North, by Sharon Chester. 71(3):352-354.

Obbard, M.E. (See Laforest, B.J.)

Okpakok, S. (See Ljubicic, G.)

Paquette-Struger, B., Wrona, F.J., Atkinson, D., and Di Cenzo, P. Seasonal Variations in the Limnology of Noell Lake in the Western Canadian Arctic Tracked by In Situ Observation Systems. 71(2):149-166.

Parlee, B. (See Southcott, C.)

Patterson, L.D. (See Straka, J.R.)

Pizzolato, L. (See Dawson, J.)

Potter, B.A. (See Glassburn, C.L.)

Pratte, I., Boadway, K.A., Diamond, A.W., and Mallory, M.L. Changes in Isotopic Niches across Stages of the Annual Cycle in the Arctic Tern (Sterna paradisaea). 71(3):259-268.

Rasmus, S. (See Turunen, M.T.)

Ray, A.J. (Book Review) White Fox and Icy Seas in the Western Arctic: The Fur Trade, Transportation, and Change in the Early Twentieth Century, by John R. Bockstoce. 71(4):458-459.

Reuther, J.D. (See Glassburn, C.L.)

Robards, M. (See Bentzen. R.)

Robertson, S. (See Ljubicic, G.)

Robidoux, M.A. (See Thompson, H.A.)

Rychkova, A. (See Kouzov, S.)

Sagitov, R. (See Kouzov, S.)

Schick, R.S. (Book Review) North Atlantic Right Whales: From Hunted Leviathan to Conservation Icon, by David W. Laist. 71(3):349-350.

Sivarajah, B. (See Stewart, E.M.)

Smol, J.P. (See Stewart, E.M.)

Smultea, M.A. (See Lomac-MacNair, K.) 
Sorum, M.S. (See Joly, K.)

Southcott, C., Abele, F., Natcher, D.C., and Parlee, B. Beyond the Berger Inquiry: Can Extractive Resource Development Help the Sustainability of Canada's Arctic Communities? 71(4): 393-406.

Ste-Marie, E., Turney, S., and Buddle, C.M. The Effect of Road Proximity on Arthropod Communities in Yukon, Canada. 71(1):89-98.

Stewart, E.M., Hargan, K.E., Sivarajah, B., Kimpe, L.E., Blais, J.M., and Smol, J.P. A Paleoenvironmental Study Tracking Eutrophication, Mining Pollution, and Climate Change in Niven Lake, the First Sewage Lagoon of Yellowknife (Northwest Territories). 71(2):201-217.

Straka, J.R., Antoine, A., Bruno, R., Campbell, D., Campbell, R. (Ron), Campbell, R. (Ross), Cardinal, J., Gibot, G., Gray, Q.Z., Irwin, S., Kindopp, R., Ladouceur, R., Ladouceur, W., Lankshear, J., Maclean, B., Macmillan, S., Marcel, F., Marten, G., Marten, L., McKinnon, J., Patterson, L.D., Voyageur, C., Voyageur, M., Whiteknife, G.S., and Wiltzen, L. "We Used to Say Rats Fell from the Sky after a Flood": Temporary Recovery of Muskrat Following Ice Jams in the Peace-Athabasca Delta. 71(2):218-228.

Streever, B. (Book Review) Sixty Degrees North: Around the World in Search of Home, by Malachy Tallack. 71(1):103.

- (See Bentzen, R.)

Striano, E. (See Crawford, R.E.)

Strindberg, S. (See Bentzen, R.)

Strong, W.L. Summer Climatic Moisture Balances for Yukon Xerophytic Grassland Slopes and Their Late-Wisconsinan Counterparts: Are Present-Day Grasslands Beringian Relicts? 71(2):139-148.

Thacher, D. Salvaging on the Coast of Erebus Bay, King William Island: An Analysis of Inuit Interaction with Material from the Franklin Expedition. 71(4):431-443.

Thiemann, G.W. (See Laforest, B.J.)

Thompson, H.A., Mason, C.W., and Robidoux, M.A. Hoop House Gardening in the Wapekeka First Nation as an Extension of Land-Based Food Practices. 71(4):407-421.
Tomaselli, M., Gerlach, S.C., Kutz, S.J., Checkley, S.L., and the Community of Iqaluktutiaq. Iqaluktutiaq Voices: Local Perspectives about the Importance of Muskoxen, Contemporary and Traditional Use and Practices. 71(1):1-14.

Turney, S. (See Ste-Marie, E.)

Turunen, M.T., Rasmus, S., and Kietäväinen, A. The Importance of Reindeer in Northern Finland during World War II (1939-45) and the Post-War Reconstruction. 71(2):167-182.

Virginia, R.A. (See Hansen, A.M.)

Voyageur, C. (See Straka, J.R.)

Voyageur, M. (See Straka, J.R.)

Wamsley, D.W. (Book Review) Polaris: The Chief Scientist's Recollections of the American North Pole Expedition, 1871 -73, by Emil Bessels; edited and translated by William Barr. 71(2):232-233.

Warziniack, T. (See Nong, D.)

Wells, P.J. (Commentary) Acknowledging Our Past Editor. 71(3):iii.

-. (InfoNorth) Some Unique Bone, Antler and Ivory Artefacts from Phillip's Garden (EeBi-1), a Dorset Paleo-Inuit Settlement in Northwestern Newfoundland. 71(3):355-359.

White, G. (Book Review) Too Many People: Contact, Disorder, Change in an Inuit Society, 1822-2015, by Willem Rasing. 71(4):459-460.

Whiteknife, G.S. (See Straka, J.R.)

Willoughby, A.L. (See Clarke, J.T.)

Wiltzen, L. (See Straka, J.R.)

Woo, M.-K. (Book Review) Geocryology: Characteristics and Use of Frozen Ground and Permafrost Landforms, by Stuart A. Harris, Anatoli Brouchkov and Cheng Guodong. 71(2):233-235.

Wooller, M.J. (See Glassburn, C.L.)

Wrona, F.J. (See Paquette-Struger, B.)

Young, M.G. (Book Review) No Home in a Homeland: Indigenous Peoples and Homelessness in the Canadian North, by Julia Christensen. 71(2):229-230.

Zack, S. (See Bentzen, R.)

Zaynagutdinova, E. (See Kouzov, S.) 